\title{
Detection of gamma irradiated South Sea cultured pearls II
}

\author{
Hyunmin $\mathrm{Choi}^{\dagger}$, Bohyun Lee and Youngchool Kim \\ Hanmi Gemological Laboratory (Hanmi Lab), Seoul 110-390, Korea
}

(Received July 23, 2012)

(Revised July 26, 2012)

(Accepted August 3, 2012)

\begin{abstract}
It is very difficult to detect irradiated South Sea cultured pearls (SSCPs) at a low dose by gemological methods (e.g. optical transmission method, microscopic examination, UV fluorescence reaction, and so on). In this study, however, it was possible to distinguish between irradiated SSCPs from un-irradiated SSCPs by ESR analysis. We have analyzed the pearl nacre and nucleus by separating them for the purposed of providing information about the change of $\mathrm{CO}_{2}^{-}$radical as growing absorbed doses. And it was found out that the signal of $\mathrm{CO}_{2}^{-}$radical of the nacre is more distinct than the nucleus.
\end{abstract}

Key words Irradiated South Sea cultured pearls, Low dose, ESR analysis, $\mathrm{CO}_{2}^{-}$Radical, Pearl nacre

\section{감마선 조사된 남양진주의 검지 II}

최현민 ${ }^{\dagger}$, 이보현, 김영출

한미보석감정원, 서울, $110-390$

(2012년 7월 23일 접수)

(2012년 7월 26일 심사완료)

(2012년 8월 3일 게재확정)

요 약 방사선 조사된 남양진주는 광투과 검사, 확대 검사, 형광반응 검사 등의 보석학적 검사방법으로는 감별이 어렵 지만, ESR 분석을 통해 조사된 남양진주와 조사되지 않은 남양진주의 감별이 가능하였다. 본 연구에서는 조사선량이 증가 함에 따른 $\mathrm{CO}_{2}^{-} \mathrm{radical}$ 의 변화와 관련된 정보를 제공할 목적으로 진주층과 핵을 분리하여 분석하였으며, 핵보다는 진주층 에서 $\mathrm{CO}_{2}^{-}$radical이 더 명료하게 나타남을 발견하였다.

\section{1. 서 론}

방사선을 이용한 진주의 색상 처리는 오래 전부터 행 해져 왔다. 주로 흑진주의 대용품으로 만들기 위해 해수 진주와 담수진주를 조사 처리하였으며, 일부 진주는 광 택의 개선을 위해 조사 처리를 행하였다고 보고된 바도 있다[1-3]. 최근에는 방사선 조사 처리가 아코야진주 (Akoya cultured pearls), 담수진주(Freshwater cultured pearls) 뿐만 아니라 남양진주(South Sea cultured pearls) 에까지 이루어지고 있다[4].

진주의 색은 진주층에 함유된 단백질 색소에 의하여 cream, yellow, black 등의 색이 결정되기도 하고, 진주

\footnotetext{
Corresponding author

Tel: +82-2-3672-2800

Fax: +82-2-3672-2803

E-mail: hmcgem@hanmail.net
}

층과 진주핵 사이에 존재하는 유기물에 의하여 blue 또 는 silver gray를 띠기도 한다[5]. 한국을 포함해서 대만, 유럽의 소비자들은 주로 유기물에 의하여 생성된 silver gray의 남양진주를 선호한다.

방사선 조사된 남양진주가 한국 시장에서 인지된 것은 2011년 4월이다. 이후, 2011년 9월에 개최된 홍콩 주얼 리 쇼에서 일본의 한 업자가 한국업자에게 조사된 남양 진주임을 알리지 않고 판매한 것이 알려지게 되었다. 조 사된 남양진주는 light gray 또는 silver gray였으며, 10 $16 \mathrm{~mm}$ 크기의 나주(loose stone)와 비드(bead)였다.

아코야진주의 경우 진주층의 두께는 약 $0.2 \sim 0.6 \mathrm{~mm}$ 이기에 일반적인 보석학적 검사를 통해 방사선 조사된 진주의 감별이 가능하나, 상대적으로 진주층이 두꺼운 남양진주의 경우 진주층의 두께가 약 $1.0 \sim 3.0 \mathrm{~mm}$ 이므 로 일반적인 보석학적 검사를 통해서는 감별이 어렵다. 때문에, 발표된 『감마선 조사된 남양진주의 검지』연 
구에서 방사선 조사된 식품 등의 검지에 활용되는 $\mathrm{ESR}$ spectroscopy를 이용하여 조사된 남양진주의 감별이 가 능함을 보고한 바 있다[4].

본 연구에서는 지난 연구에서 언급하지 않은 보석학적 검사의 한계점과, 진주를 구성하는 진주층과 핵을 각각 분리하여 ESR spectroscopy를 측정하였으며 조사 후에 생성되는 특이 signal인 $\mathrm{CO}_{2}^{-}$radical의 특징에 대해 살 펴보고자 하였다.

\section{2. 실험방법}

본 실험에서는 $8 \sim 16.5 \mathrm{~mm}$ 의 남양진주 200 여 개를 $0.1 \sim 1 \mathrm{kGy}$ 의 선량으로 방사선 조사하였다. 방사선은 한 국원자력연구원 방사선 조사시설의 ${ }^{60} \mathrm{Co} \gamma$-ray를 이용하 였다. ESR 측정은 $\mathrm{Mn}$ marker가 장착된 Joel사의 Xband ESR spectroscopy(FA300)를 이용하였다. ESR spectroscopy의 실험조건은 microwave frequency 9.8 $\mathrm{GHz}$, microwave power $2 \mathrm{~mW}$, modulation amplitude $1 \sim 2 \mathrm{G}$, signal channel의 time constant $0.1 \mathrm{sec}$, sweep time $1 \mathrm{~min}$ 등이었으며 방사선 조사로 생성된 $\mathrm{CO}_{2}^{-}$

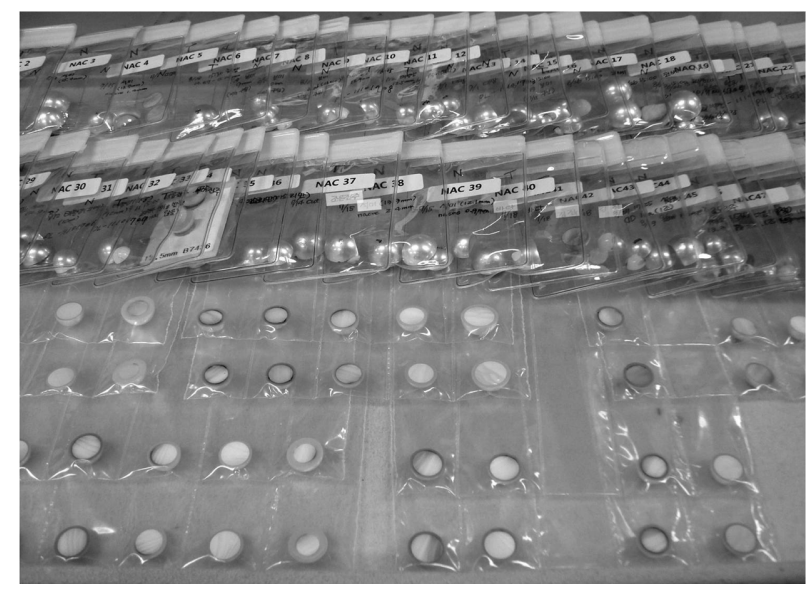

Fig. 1. Shown here are some of the South Sea cultured pearls examined as part of this study. radical의 변화와 검지 여부를 알아보기 위하여 진주층과 핵을 분리하여 선량에 따라 각각 $\mathrm{ESR}$ 을 측정하였다.

\section{3. 결과 및 고찰}

방사선 조사된 진주를 판별하기 위한 일반적인 보석학 적 방법으로는 광투과 검사와 확대 검사, 형광반응 검사 등이 있다[3,5]. 광투과 검사는 높은 선량으로 조사된 진주의 경우 핵이 흑화되기 때문에 빛을 투과시켜 관찰 했을 때 진주의 중심부가 어둡게 보이고 투과 빛은 dark orange로 보이는 반면에 조사되지 않은 진주는 밝으며 yellow-white로 보인다(Fig. 2). 그러나 최근에 나타난 방사선 조사된 남양진주는 조사 선량이 $0.3 \sim 1 \mathrm{kGy}$ 정도 이며, 광투과 검사에서는 Fig. 2a와 흡사하게 보이기 때 문에 처리되지 않은 진주와 구별이 어렵다.

확대 검사는 주로 진주의 드릴 된 부분을 관찰하는데, Fig. 3a에서 보이는 것처럼 조사 처리되지 않은 진주는 진주층 내부에 있는 핵의 색이 white에 가깝지만, 조사 처리된 진주는 black 또는 dark gray에 가깝게 나타난다 (Fig. 3c). 그러나 최근에 나타난 낮은 선량으로 방사선 조사된 남양진주는 처리되지 않은 진주와 비교해 볼 때 큰 차이가 없다(Fig. $3 \mathrm{~b})$. 진주의 드릴 된 부분의 확대 검사 또한 처리되지 않은 진주와 구분이 어려움을 보여

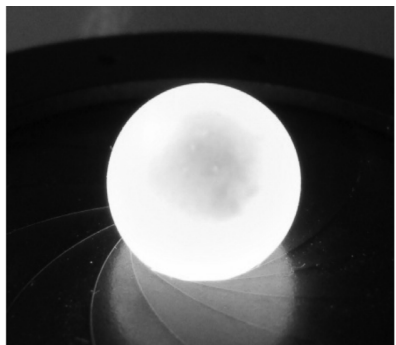

(a)

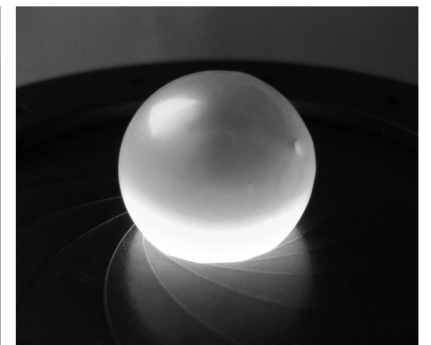

(b)
Fig. 2. Seawater cultured pearls observed by the optical transmission method; (a) untreated pearl and (b) irradiation treated pearl more $30 \mathrm{kGy}$ absorbed dose.

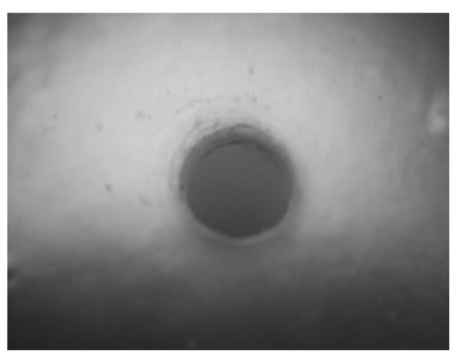

(a)

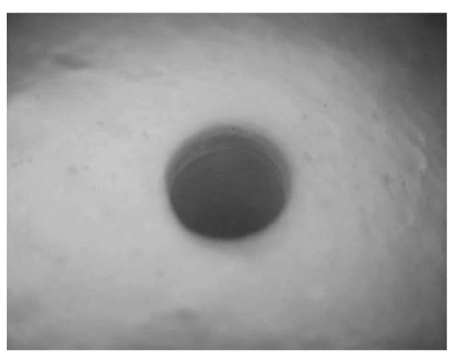

(b)

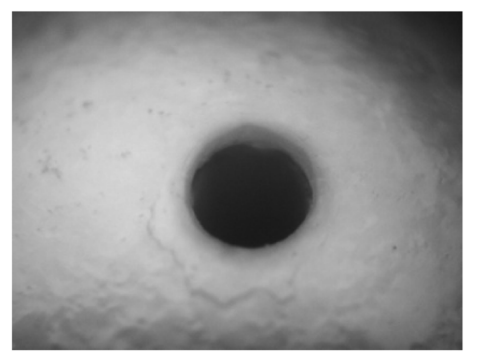

(c)

Fig. 3. Seawater cultured pearls observed through the drilled hole by microscopic examination; (a) untreated pearl (b) irradiation treated pearl by low-dose of $1 \mathrm{kGy}$ and (c) irradiated pearl more than $30 \mathrm{kGy}$ dose. 


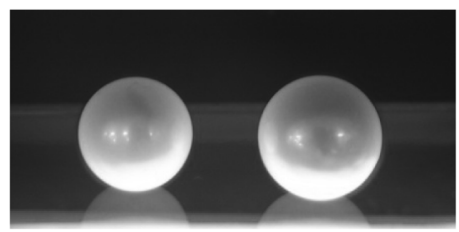

(a)

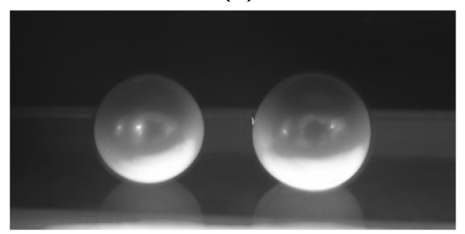

(d)

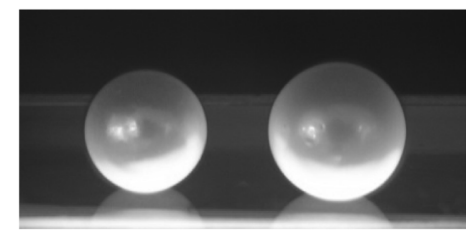

(b)

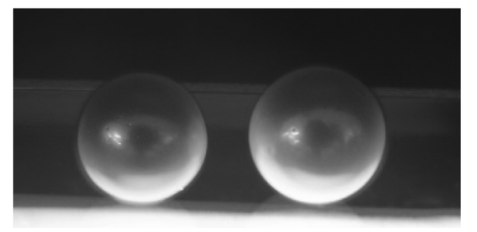

(e)

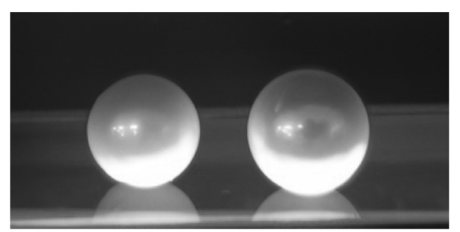

(c)

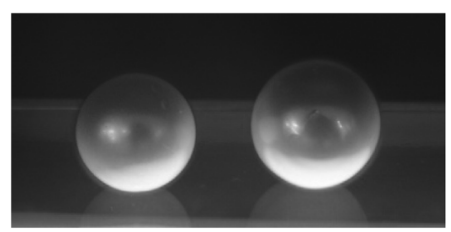

(f)

Fig. 4. The UV fluorescence reaction of South Sea cultured pearls by increasing irradiation dose; (a) unirradiated, (b) $0.5 \mathrm{kGy}$, (b) $1 \mathrm{kGy}$, (c) $5 \mathrm{kGy}$, (d) $10 \mathrm{kGy}$, (e) $30 \mathrm{kGy}$ and (f) $100 \mathrm{kGy}$.

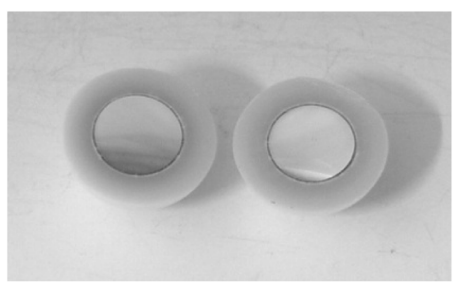

(a)

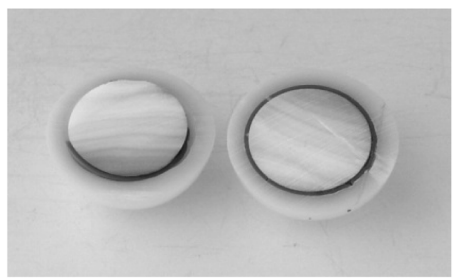

(c)

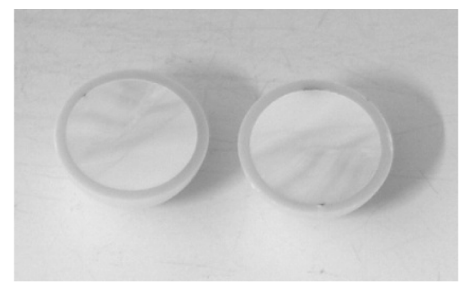

(b)

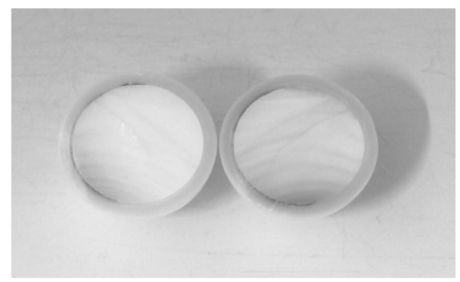

(d)

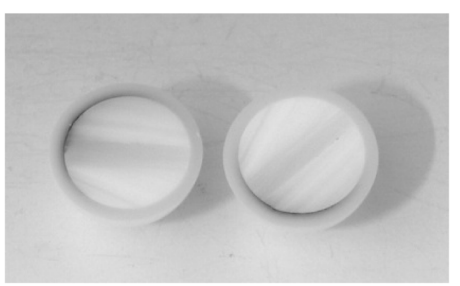

(e)

Fig. 5. The cross-section of a low-dose irradiated and unirradiated South Sea cultured pearls; (a), (b): irradiated below 1 kGy, (c), (d), (e): unirradiated.

주는 예라 할 수 있다.

Fig. 4는 조사 선량이 증가함에 따라 자외선 장파 (long-wave UV)에서 보여지는 형광반응을 나타낸 것이 다. 조사되기 전에는 청백색의 형광반응이 두드러짐을 볼 수 있으나 조사 선량이 증가할수록 청백색의 형광반 응이 감소함을 볼 수 있다. Fig. 4의 a, b에서 볼 수 있 듯이 $1 \mathrm{kGy}$ 선량까지는 처리되지 않은 진주가 나타내는 청백색의 형광반응을 볼 수 있지만 $5 \mathrm{kGy}$ 에서는 청백색 의 형광반응이 현저히 줄었으며, $10 \mathrm{kGy}$ 이상에서는 청 백색의 형광반응이 모두 사라짐을 확인할 수 있다. 이는 $10 \mathrm{kGy}$ 이상의 선량으로 조사된 진주는 형광반응으로 식별할 수 있는 수단이 되지만, $0.5 \mathrm{kGy}$ 정도의 선량으 로 조사된 진주는 조사되지 않은 진주와의 구분이 쉽지 않음을 의미한다.

방사선 조사에 의한 색상 변화는 진주층의 두께에도 영향을 받는다. 아코야진주는 진주층이 $0.2 \sim 0.6 \mathrm{~mm}$ 정
도로 얇기 때문에 변화된 핵의 결과가 진주층을 통해 잘 투영되어 보이는 반면, 남양진주의 진추층은 보통 1 $3 \mathrm{~mm}$ 로 두껍기 때문에 변화된 핵의 색상이 진주층을 통 해 잘 투영되지 못한다[4]. 더불어 높은 선량으로 조사 된 진주는 핵의 흑화가 두드러지지만[6] 낮은 선량으로 조사된 진주는 핵의 흑화 정도가 두드러지지 않다. 이는 Fig. 5에 나타내었다. Fig. 5의 a, b는 $1 \mathrm{kGy}$ 이하로 조 사된 진주를 절단하여 핵과 진주층을 관찰한 것이고, Fig. 5의 c, d, e는 조사되지 않은 진주를 관찰한 것이다. 진주의 내부를 구성하는 핵은 패각(shell)의 일부분을 가 공하여 만들기 때문에 패각 특유의 구조가 반영된 곡선 의 층상구조가 관찰된다. 이러한 곡선형 층상구조는 방 사선 조사선량이 증가할수록 핵의 전체 색상이 어두워지 며 층상구조의 음영차이가 발생되는데 이는 조사 여부를 식별할 수 있는 수단이 되기도 한다. 그러나, Fig. 5의 진주는 조사되지 않은 진주와 조사된 진주의 핵의 차이 

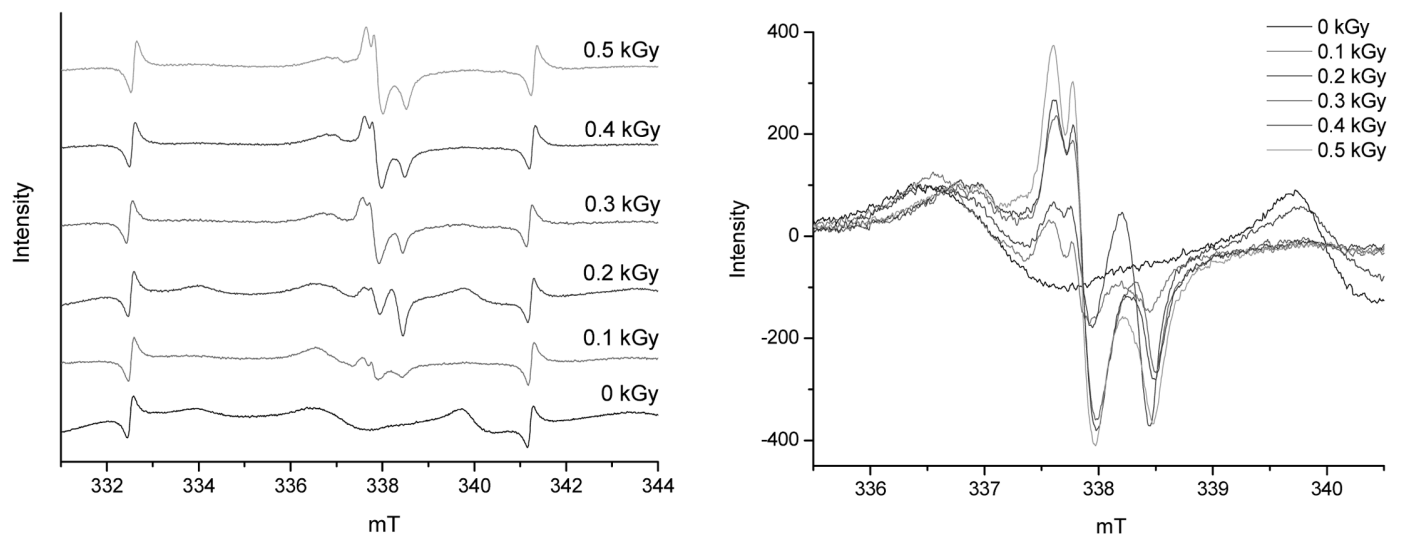

Fig. 6. ESR spectra of South Sea cultured pearls. These are the results from before irradiation and up to irradiation at a dose of $0.5 \mathrm{kGy}$.

가 거의 없음을 볼 수 있다.

앞에서 살펴본 바와 같이 일반적인 보석학적 방법(광 투과 검사, 확대 검사, 형광반응 검사 등)은 높은 선량으 로 조사되었을 경우 식별의 수단이 될 수는 있지만, 낮 은 선량 $(0.3 \sim 1 \mathrm{kGy})$ 으로 조사 처리가 이루어졌을 경우 조사되지 않은 진주와 식별이 어려움을 확인하였다.

Fig. 6은 ESR spectroscopy를 이용하여 측정한 결과이 다. Free radical의 정확한 위치 보정을 위하여 $\mathrm{Mn}$ marker를 동시에 사용하여 분석하였다. 방사선 조사 전 에는 존재하지 않았던 $\mathrm{CO}_{2}^{-}$radical이 조사 후에 새롭게 생성됨을 확인하였으며, 조사 후 생성된 $\mathrm{CO}_{2}^{-}$radical은 조사 선량이 증가함에 따라 intensity도 동시에 증가함을 볼 수 있다. 따라서, $\mathrm{ESR}$ 분석을 통한 $\mathrm{CO}_{2}^{-}$radical의 존재 여부의 확인은 조사된 진주와 조사되지 않은 진주 를 구별할 수 있는 수단이 될 수 있다.

$\mathrm{CO}_{2}^{-}$radical은 시편의 방향에 따라 shift하는 경향을

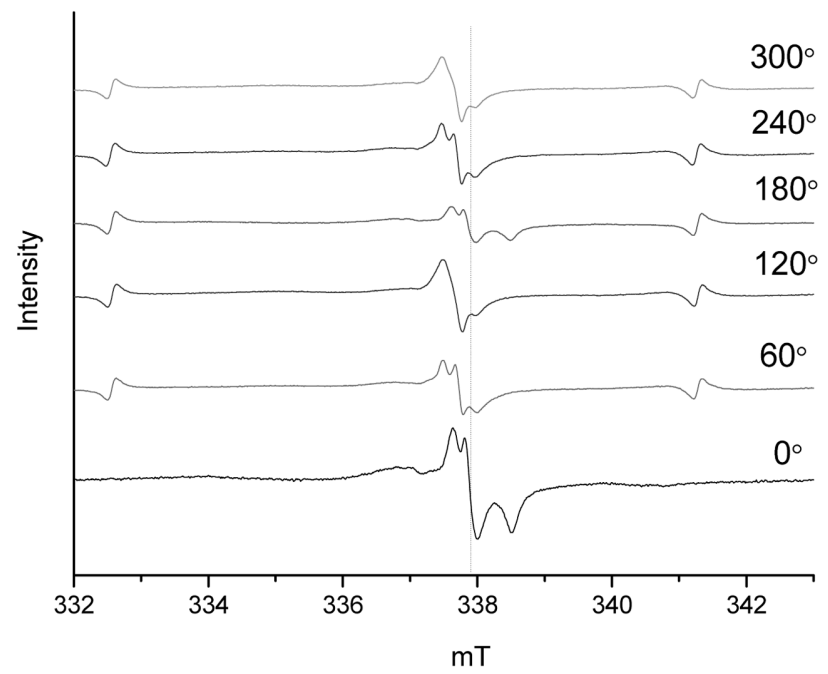

Fig. 7. ESR spectra of South Sea cultured pearls. The location and intensity of the $\mathrm{CO}_{2}^{-}$radical could be affected depending on the direction of sample.
볼 수 있었는데, 이러한 경향을 관찰하기 위해 시편을 $0^{\circ}$ 에서 $360^{\circ}$ 까지 $60^{\circ}$ 간격으로 회전시키며 측정한 결과 를 Fig. 7에 나타내었다. $\mathrm{CO}_{2}^{-}$radical의 intensity는 $0^{\circ}$ 일 때 가장 선명하게 나타났으며 시편의 각도가 바뀌면서 $\mathrm{CO}_{2}^{-}$radical의 g-factor도 조금씩 shift 되었다. 이러한 결과로 인해 조각상태인 시편의 단면과 magnetic field 가 수직인 방향이 되게 측정할 때, 생성되는 radical의 intensity도 가장 잘 나타남을 알 수 있었으며, 각도에 따 라 미세하게 shift되는 현상은 진주층이 aragonite의 결 정상을 갖기에 나타나는 이방성 때문인 것으로 사료된다.

Fig. 8은 진주층과 핵을 분리하여 각각 조사 선량에 따른 $\mathrm{CO}_{2}^{-}$radical의 intensity를 정량화한 결과이다. 조 사 선량이 증가할수록 비례하였으며, 핵보다 진주층에서 $\mathrm{CO}_{2}^{-}$radical의 intensity가 더 명료하게 나타남을 알 수 있다. 이러한 차이는 진주층과 핵에 존재하는 $\mathrm{Mg}$ 이 $\mathrm{CO}_{2}^{-}$radical의 포화 레벨과 관련 있다는 기존 문헌들의 보고로 볼 때[7-9], 진주층과 핵의 $\mathrm{Mg}$ 함량 차이로 인

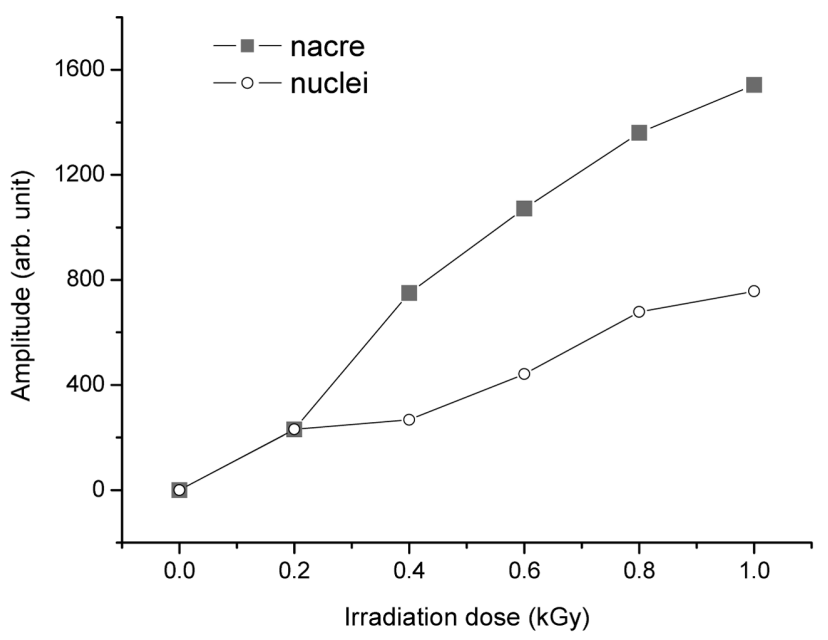

Fig. 8. Especially $\mathrm{CO}_{2}^{-}$radicals emerging were better observed in the nacre than in the nucleus. 
해 발생된 것으로 추측해 볼 수 있다.

\section{4. 결 론}

낮은 선량으로 방사선 조사된 남양진주의 감별은 보석 학적 감별로는 한계가 있다. 그러나, 본 연구의 ESR 결 과에서 나타났듯이 방사선 조사되지 않은 남양진주와 조 사 처리된 남양진주의 감별이 가능하였다. 방사선 조사 후, 방사선 조사되기 전에는 존재하지 않았던 $\mathrm{CO}_{2}^{-}$ radical이 생성되었고 이를 ESR spectroscopy를 통해 확 인이 가능하였다. $\mathrm{CO}_{2}^{-}$radical은 진주가 지니는 이방성 으로 인해 시편의 방향성에 따른 shift 현상이 발견되었 으며, 조사 선량이 증가함에 따라 비례함을 확인하였다. 더불어 $\mathrm{CO}_{2}^{-}$radical은 핵보다는 진주층에서 명료하게 나 타났다.

\section{참 고 문 헌}

[1] R. Crowningshield, "Gem Trade Lab Notes: Cultured pearls, irradiated", Gems \& Gemological 24(4) (1988) 244.

[2] L. Liping and C. Zhonghui, "Irradiation treatment of cultured pearls", Journal of Gems \& Gemological 4(3) (2002) 16.

[ 3 ] M. O'Donoghue, "Gems", $6^{\text {th }}$ ed. (Elsevier, Oxford, UK., 2006) p. 631.

[4] H.M. Choi, B.H. Lee and Y.C. Kim, "Detection of gamma irradiated South Sea cultured pearls", Journal of the Korean Crystal Growth and Crystal Technology 22(1) (2012) 36.

[5] H. Komatsu, "The identification of pearls in Japan-A status quo summary", Journal of the Gemmological Society of Japan 20(1-4) (1999) 111.

[6] K. Wada, "Science of pearl" (Pearl Newspaper Company, Toyko, 1999) p. 187.

[ 7 ] M. Ikeya, "New applications of electron spin resonance - dating, dosimetry and microscopy", ed. Zimmerman M.R., Whitehead N. (World Scientific, Singapore, 1993) p. 179.

[ 8 ] M. Barabas, A.Bach, M. Mudelsee and A. Mangini, "General properties of the paramagnetic centre at $\mathrm{g}=2.0006$ in carbonates", Quaternary science reviews 11 (1992) 165

[9] A. Katz, "The interaction of magnesium with calcite during crystal growth at $25 \sim 90^{\circ} \mathrm{C}$ and one atmosphere", Geochimica et Cosmochimica Acta 37(6) (1973) 1563. 